\title{
Forage intake, feeding behavior and bio-climatological indices of pasture grass, under the influence of trees, in a silvopastoral system
}

\author{
L.F. SOUSA ${ }^{1}$, R.M. MAURÍCIO ${ }^{2}$, D.S.C. PACIULLO ${ }^{3}$, S.R. SILVEIRA ${ }^{2}$, R.S. RIBEIRO ${ }^{2}$, L.H. CALSAVARA ${ }^{2}$ \\ AND G.R. MOREIRA ${ }^{4}$ \\ ${ }^{1}$ Departamento de Zootecnia, Universidade Federal do Tocantins, Palmas, TO, Brazil. http://ww1.uft.edu.br \\ ${ }^{2}$ Departamento de Engenharia de Biossistemas (DEPEB), Universidade Federal de São João Del-Rei, São João Del- \\ Rei, MG, Brazil. www.ufsj.edu.br/ppbe \\ ${ }^{3}$ Empresa Brasileira de Pesquisa Agropecuária, Embrapa Gado de Leite, Juiz de Fora, MG, Brazil. \\ www.embrapa.br/en/gado-de-leite \\ ${ }^{4}$ Departamento de Estatística e Informática, Universidade Federal Rural de Pernambuco, Recife, PE, Brazil. \\ www.deinfo.ufrpe.br
}

Keywords: Animal behavior, microclimate, shade, sheep.

\begin{abstract}
The aim of this study was to compare a silvopastoral system with a control (pasture only) in the Brazilian Cerrado. The silvopastoral system consisted of a tropical grass (Brachiaria brizantha cv. Marandu) pasture and trees (Zeyheria tuberculosa), while the control was a Marandu pasture without trees. Sheep intake, feeding behavior and microclimatic conditions were the variables evaluated. Temperatures within the silvopastoral system were lower than in the control (maximum temperature of 28 and $33.5^{\circ} \mathrm{C}$, temperature and humidity index of 74.0 and 79.2 for the silvopastoral system and control, respectively). There was increased dry matter intake ( $\left.88.2 \mathrm{vs.} 79.9 \mathrm{~g} \mathrm{DM} / \mathrm{kg}^{0.75} \mathrm{LW} / \mathrm{d}, \mathrm{P}<0.05\right)$, organic matter intake $\left(89.6\right.$ vs. $\left.81.1 \mathrm{~g} \mathrm{OM} / \mathrm{kg}^{0.75} \mathrm{LW} / \mathrm{d}, \mathrm{P}<0.05\right)$ and grazing time $(572 \mathrm{vs.} 288 \mathrm{~min} / \mathrm{d}, \mathrm{P}<0.05)$, and reduced total water intake $\left(430\right.$ vs. $\left.474 \mathrm{~mL} / \mathrm{kg}^{0.75} \mathrm{LW} / \mathrm{d}, \mathrm{P}<0.05\right)$ and walking time $(30 \mathrm{vs} .89 \mathrm{~min} / \mathrm{d}, \mathrm{P}<0.05)$ in grazing sheep in the silvopastoral system relative to the control. The results suggest that a silvopastoral system would provide a more favorable environment than a straight pasture for sheep performance in a tropical grazing situation.
\end{abstract}

\section{Resumen}

En el estudio se compararon un sistema silvopastoril con un sistema control de solo pastura en condiciones del Cerrado brasileño. El sistema silvopastoril consistió en una pastura de Brachiaria brizantha cv. Marandu con árboles de Zeyheria tuberculosa, mientras que el tratamiento control consistió en una pastura de cv. Marandu sin árboles. Como variables se midieron el consumo por ovejas, su comportamiento de pastoreo y las condiciones microclimáticas durante el tiempo de evaluaciones. Las temperaturas para el sistema silvopastoril fueron más bajas que en el control (temperatura máxima de 28 y $33.5^{\circ} \mathrm{C}$, e índice de temperatura-humedad de 74.0 y 79.2 para el sistema silvopastoril y el control, respectivamente). Las ovejas en pastoreo mostraron mayor consumo de materia seca (88.2 vs. $79.9 \mathrm{~g}$ $\mathrm{MS} / \mathrm{kg}^{0.75}$ peso vivo/día, $\left.\mathrm{P}<0.05\right)$ y de materia orgánica ( $89.6 \mathrm{vs.} 81.1 \mathrm{~g} \mathrm{MO} / \mathrm{kg}^{0.75}$ peso vivo/día, $\left.\mathrm{P}<0.05\right)$, mayor tiempo pastoreando (572 vs. 288 minutos/día, $\mathrm{P}<0.05$ ), menor consumo total de agua (430 vs. $474 \mathrm{~mL} / \mathrm{kg}^{0.75}$ peso vivo/día, $\mathrm{P}<0.05)$ y menor tiempo caminando (30 vs. 89 minutos/día, $\mathrm{P}<0.05$ ) en el sistema silvopastoril en comparación con el sistema control. Los resultados indican que para la producción ovina bajo condiciones tropicales un sistema silvopastoril puede proporcionar un entorno más favorable que un sistema de pastura sola.

\footnotetext{
Correspondence: Rogério M. Maurício, Departamento de Engenharia de Biossistemas (DEPEB), Universidade Federal de São João DelRei, Campus Dom Bosco, Pç Dom Helvécio, 74 - Dom Bosco, CEP 36301-160, São João Del-Rei, MG, Brazil.

E-mail: rogeriomauricio@ufsj.edu.br
} 


\section{Introduction}

Silvopastoral systems (SPS), a combination of trees, forages and animals, are increasingly being adopted throughout the tropics as a sustainable alternative to straight pasture for animal production, consequently reducing the impacts of deforestation (Bocquier and Gonzalez-Garcia 2010; Maurício 2012) and increasing biodiversity (Dumont et al. 2013). In these systems, the dynamics of ecophysiological processes are different from those in traditional monoculture forage systems (Wilson et al. 1990). According to Maurício (2012), SPS require more complex management owing to the larger number of interactions between the different plant forms.

Trees in SPS take up nutrients from deeper layers in the soil and make them available to forage through the decomposition of leaves, twigs, flowers and fruits, which fall to the ground, thus improving soil fertility and, consequently, the quality and yield of the pasture (Reis et al. 2009). This can directly influence animal performance, since both quality and availability of nutrients are correlated with forage intake. Another positive aspect should be the reduction of environmental stress on animals due to the interaction between tree shade and animal behavior. The reduction of sunlight and ambient temperature provided by the tree shade should have an important microclimatic benefit for animals, resulting in increased forage intake and production (Paciullo et al. 2011) and reduction in the expenditure of metabolic energy to maintain homeostatic equilibrium (Forbes 1995).

The objective of this study was to compare the intake and feeding behavior of sheep and microclimatic conditions in a tropical grass [Brachiaria brizantha (now Urochloa brizantha (Hochst. ex A. Rich.) R.D. Webster) cv. Marandu] pasture, with and without the native tree species, bolsa-de-pastor [Zeyheria tuberculosa (Vell.) Bureau] during the rainy season in the Brazilian Cerrado ecosystem.

\section{Materials and Methods}

\section{Location and treatments}

The experiment was conducted in a silvopastoral system area on a private farm, in Lagoa Santa municipality,

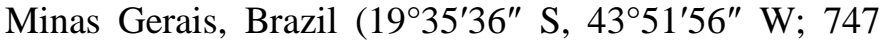
masl). There were 2 system treatments: silvopastoral system (SPS; = grass plus trees) and monoculture (Mono; = grass only). According to the Brazilian soil classification, for both systems the soil is a red-yellow oxisol ('latossolo vermelho-amarelo'; Typic Acrustox -
USDA classification) with $651 \mathrm{~g} / \mathrm{kg}$ clay, $211 \mathrm{~g} / \mathrm{kg}$ silt and $138 \mathrm{~g} / \mathrm{kg}$ sand. The P level, in the 0-20 $\mathrm{cm}$ layer of both systems, was $1 \mathrm{mg} / \mathrm{dm}^{3}$, while the $\mathrm{pH}$ level was 5.1 in the SPS and 4.9 in Mono (Reis et al. 2009). The silvopastoral system area on that farm (Figure 1) had been under development since 1984 by: managing the natural regeneration of the tree, Zeyheria tuberculosa (ZT); replacement of the grass Hyparrhenia rufa by Marandu; application, guided by soil analyses, of only modest rates of limestone and rock phosphate ( 1 and 0.5 tonne/ha, respectively); and no use of (soil organic matter deteriorating) fire as traditional pasture management tool.

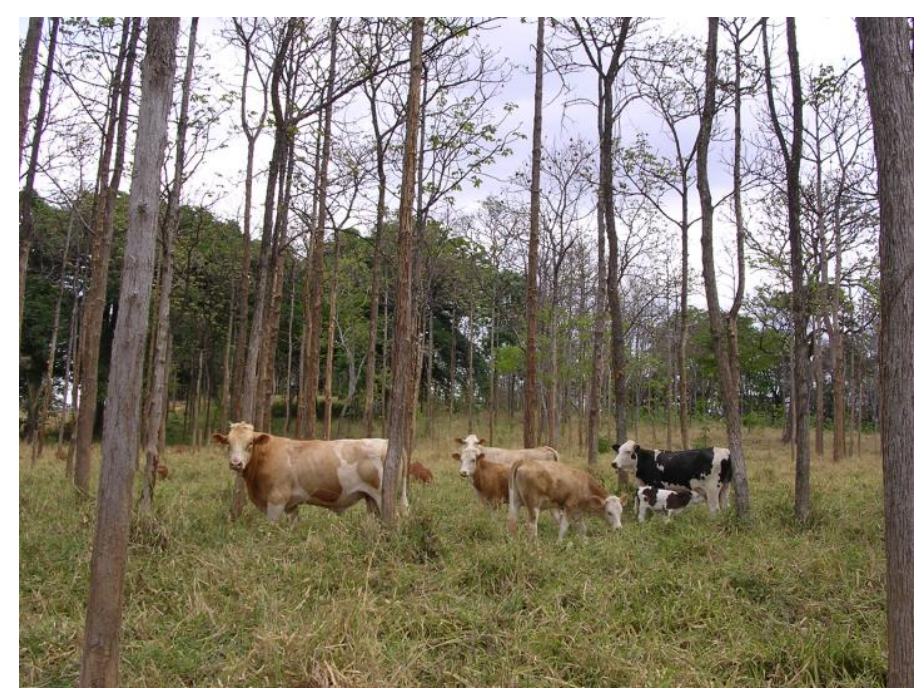

Figure 1. Silvopastoral system with Urochloa brizantha cv. Marandu and the tree, Zeyheria tuberculosa (bolsa-de-pastor).

The tree species was selected for inclusion in the SPS owing to the quality of its wood, its fast growth, straight trunks, intermediate canopy density and resistance to cattle grazing. It is a very useful species for restoring degraded areas through natural regeneration, as its seeds are easily spread by wind. During the natural regeneration process prior to the commencement of the trial (June 2001), undesirable species were removed and at least $4 \mathrm{~m}$ were kept between ZT trees. At commencement, the trees were $15-23 \mathrm{~m}$ tall with a crown stem diameter of $40-60 \mathrm{~cm}$. The density adopted was 160 trees/ha.

For the control treatment (Mono), an adjacent area, from which all trees were removed, was planted with Marandu using the same methodology. The total area, including the SPS and the pasture, consisted of approximately 2 ha. 
The experiment consisted of: (1) assessment of forage grass production during 12 months and, in the rainy season when there was adequately high forage production, (2) a sheep intake and feeding behavior trial ("in vivo trial") during 12 days, coupled with (3) the assessment of relevant microclimatic variables.

\section{Forage production}

Within each treatment, 3 individual plots, with an area of $4 \times 4 \mathrm{~m}\left(16 \mathrm{~m}^{2}\right)$ each, were randomly allocated and fenced with barbed wire to avoid interference from the sheep that were grazing in the surrounding area. At the beginning of the rainy season (November 25 in Year I), the Marandu stands on all plots were cut at $30 \mathrm{~cm}$ from ground level to make them uniform and a $30-\mathrm{d}$ rest period was allowed for the stands to reach $60-80 \mathrm{~cm}$ in height as suggested for correct morphophysiological management (Costa et al. 2004). A single forage sample in each plot was harvested at $30 \mathrm{~cm}$ using the square method $\left(1 \mathrm{~m}^{2}\right)$, thus simulating the correct management of Marandu (Johnson 1978). After cutting, forage samples were weighed, separated into green leaf and stem, dried in a forced-air oven at $55^{\circ} \mathrm{C}$, ground in a mill using a 1-mm mesh screen, and kept in plastic containers for further analyses. This procedure was performed during 7 growth periods over 12 months as described in Table 1.

\section{Microclimatic variables}

To obtain information about thermal comfort provided by the trees, the following microclimatic parameters were measured during the intake and feeding behavior trial (12 days): global radiation (GR), maximum and minimum air temperatures were measured daily with an alcohol thermometer taken at least $3.5 \mathrm{~m}$ from the tree stems and at $1.2 \mathrm{~m}$ above ground level, along with daily average rainfall. Temperature measurements from a dry/wet bulb thermometer and a black globe thermometer (Vernon's globe thermometer) were performed 6 times a day $(07.00,09.00,11.00,13.00,15.00$ and
$19.00 \mathrm{~h}$ ) during the entire period of the in vivo trial in order to establish:

A) The temperature and humidity index (THI) according to Kelly and Bond (1971):

$\mathrm{THI}=\mathrm{DBT}-0.55(1-\mathrm{RH}) \times(\mathrm{DBT}-58)$

where:

$\mathrm{THI}=$ temperature and humidity index;

DBT $=$ dry bulb temperature $\left({ }^{\circ} \mathrm{C}\right)$; and

$\mathrm{RH}=$ relative humidity $(\%)$.

B) The black globe temperature and humidity index (BGTHI) according to Buffington et al. (1981):

$\mathrm{BGTHI}=\mathrm{TBG}+(0.36 \times \mathrm{TDP})+41.5$

where:

TBG $=$ temperature of black globe $\left({ }^{\circ} \mathrm{C}\right)$; and

$\mathrm{TDP}=$ temperature of dew point $\left({ }^{\circ} \mathrm{C}\right)$

$\mathrm{TDP}=(\mathrm{RH} / 100)^{0.125} \times[112+(0.9 \times \mathrm{DBT})]+(0.1 \mathrm{x}$

DBT) -112

Intake

For the intake trial, 18 mongrel hair sheep (aged 2-4 years) were randomly assigned to 2 groups of 9 animals (4 males and 5 non-pregnant females) with mean weights of $27.6 \pm 5.3$ and $28.3 \pm 4.9 \mathrm{~kg}$ and mean body scores of 2.00 and 2.03 (scale: $0=$ extremely thin to $5=$ extremely obese) for the SPS and Mono at commencement, respectively. On 25 November, the animals were de-wormed and after 15 days were allocated to the pasture treatments for an adaptation period of 45 days. A continuous stocking system was used at 9 animals/ha, with average initial pasture height of $50 \mathrm{~cm}$ during the late period of adaptation. A supply of green leaf dry matter of approximately 3-4\% of mean live weight was maintained. At the beginning of the in vivo trial, the stocking rate in both pastures was adjusted according to green leaf yield which could support the equivalent of up to 1.5 animal units ( $1 \mathrm{AU}=450 \mathrm{~kg})$ per ha.

Table 1. Experimental harvest periods for forage.

\begin{tabular}{lll}
\hline Harvest & Season & Data \\
\hline P1 & Rainy & 24 Nov to 25 Dec - Year I \\
P2 & Rainy & 26 Dec to 25 Jan - Year II \\
P3 & Rainy & 26 Jan to 25 Feb - Year II \\
P4 & Rainy & 26 Feb to 28 Mar - Year II \\
P5 & Transition rainy-dry & 29 Mar to 28 Apr - Year II \\
P6 & Dry & 29 Apr to 28 Jul - Year II \\
P7 & Transition dry-rainy & 29 Jul to 23 Nov - Year II \\
\hline
\end{tabular}


For both treatments (SPS and Mono), the animals had access to potable water and a trough with a commercial mineral salt mixture, specific for sheep. Disappearances of water and salt on each treatment were recorded every second day. Estimates of evapotranspiration were made through "class A" tanks in both treatments, to adjust water intakes. Total water intake was calculated as free water intake (water disappearance less evapotranspiration) plus water intake from feed (moisture content of forage consumed).

Forage samples were collected daily by means of the simulated grazing technique described by Johnson (1978). After cutting, forage samples were weighed, predried in a forced-air oven at $55{ }^{\circ} \mathrm{C}$, ground in a Willey mill equipped with a $1-\mathrm{mm}$ mesh screen, and kept in plastic containers for later laboratory analyses. Dry matter (DM), ash, nitrogen, ether extract, lignin and acid detergent fiber (ADF) were analyzed according to AOAC (2009). Neutral detergent fiber (NDF) was assayed using the procedure described by Van Soest et al. (1991) without the use of $\alpha$-amylase. NDF and ADF were expressed inclusive of residual ash. Acid detergent insoluble crude protein was assayed according to Licitra et al. (1996).

During the intake trial the animals weighed $35.2 \pm 5.2$ and $33.4 \pm 6.3 \mathrm{~kg}$ and had mean body scores of 2.90 and 2.71 for the SPS and Mono, respectively. Intake was estimated 8 days after the adaptation period, using the external indicator LIPE $^{\circledR}$, for estimating digestibility and fecal production in ruminants (Ferreira et al. 2009), supplied as capsules introduced directly into the oesophagus of the animal for 5 consecutive days in a daily dose $(0.25 \mathrm{~g} / \mathrm{animal} / \mathrm{d})$ at $08.00 \mathrm{~h}$. On the second day of administration of the external indicator LIPE ${ }^{\circledR}$, simulated grazing (SG) according to Johnson (1978) was done at 08.00 and $17.00 \mathrm{~h}$ for each animal group (treatment) and the pooled forage used in the estimation of in vitro dry matter digestibility (IVDMD) and in vitro organic matter digestibility (IVOMD). On the third day, feces collecting
(FC) began, directly from the animal's rectum, at the same time for 5 consecutive days. These samples were frozen at $-20{ }^{\circ} \mathrm{C}$ and, at the end of all collections, a pooled sample was prepared for each animal for subsequent laboratory analyses. The schemes for delivery of the indicator, simulated grazing and collection of feces are described in Figure 2.

In the laboratory, samples were thawed at room temperature, dried at $55{ }^{\circ} \mathrm{C}$ for $72 \mathrm{~h}$ in a forced-air oven, ground to $1 \mathrm{~mm}$ (Willey type mill) and analyzed for DM, OM and ash following AOAC (2009) and for Klason lignin (Theander and Westerlund 1986). For the determination of LIPE $^{\circledR}$ concentration, each sample was mixed with potassium bromide, pressed, pelleted and read by infrared spectroscopy (Boeriu et al. 2004).

Fecal production (FP) was calculated using the formulae described by Prigge et al. (1981):

$\mathrm{FP}(\mathrm{kg} \mathrm{DM} / \mathrm{animal} / \mathrm{d})=\frac{\text { Indicator ingested }(\mathrm{g} / \mathrm{animal} / \mathrm{d})}{\text { Indicator in feces }(\mathrm{g} / \mathrm{kg} \mathrm{DM})}$

$\mathrm{FP}(\mathrm{kg} \mathrm{OM} /$ day $)=\frac{\text { Indicator ingested }(\mathrm{g} / \mathrm{animal} / \mathrm{d})}{\text { Indicator in feces }(\mathrm{g} / \mathrm{kg} \mathrm{OM})}$

DM and OM intakes were obtained by the following equations:

$\mathrm{DMI}=[\mathrm{FP}$ on a DM basis $] /(1-\mathrm{IVDMD} / 1000)+\mathrm{MSI}$ $\mathrm{OMI}=[\mathrm{FP}$ on an OM basis $] /(1-\mathrm{IVOMD} / 1000)$

where:

$\mathrm{DMI}=$ total dry matter intake $(\mathrm{kg} \mathrm{DM} / \mathrm{animal} / \mathrm{d})$;

$\mathrm{OMI}=$ total organic matter intake $(\mathrm{kg} \mathrm{OM} / \mathrm{animal} / \mathrm{d})$;

IVDMD = in vitro dry matter digestibility $(\mathrm{g} \mathrm{DM} / \mathrm{kg}$ $\mathrm{DM})$

IVOMD $=$ in vitro organic matter digestibility $(\mathrm{g} \mathrm{OM} / \mathrm{kg}$ $\mathrm{OM})$; and

MSI = mineral salt intake $(\mathrm{kg} / \mathrm{animal} / \mathrm{d})$.

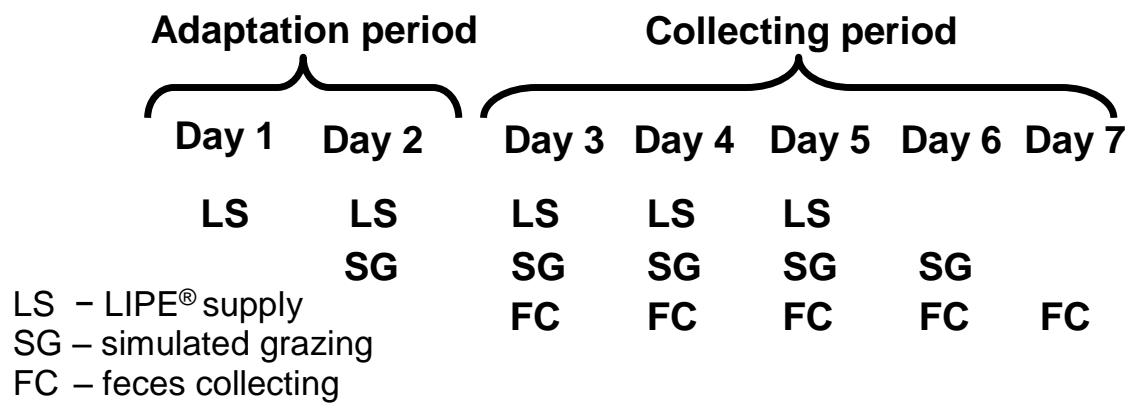

Figure 2. Procedure for delivery of the indicator, simulated grazing and collection of feces. 


\section{Feeding behavior}

The feeding behavior trial began 5 days before the intake trial and 47 days after the beginning of the adaptation period, and continued for 3 consecutive days, using the same animals and grazing systems as for the intake trial. The behavior of each animal was observed and recorded every 10 minutes during 2 periods of $24 \mathrm{~h}$ with a day of rest between periods of observations, within the following ethological categories: grazing; ruminating (either standing or lying); resting; walking; drinking; and other. During these observations, the same microclimatic parameters used for the intake trial were also measured. Since management consisted of releasing the animals in the pasture at $06.00 \mathrm{~h}$ and sheltering them for the night at $19.00 \mathrm{~h}$, night-time observations were made with the animals inside each paddock.

\section{Statistical analyses}

The statistical design used for all parameters related to the intake and behavior trials was completely randomized with 9 replicates (animals), and comparisons made by means of the $\mathrm{F}$ test at $5 \%$ probability. Regression analysis was done involving the microclimatic parameters DBT, RH, THI and BGTHI, whereas the equations were compared, across treatments, by the test for equality parameters and parallelism in non-linear regression models (Cohen 1983).

\section{Results}

\section{Forage production}

Total dry matter (TDM) production of Marandu during the rainy season $(\mathrm{P} 1-\mathrm{P} 4)$ was similar $(\mathrm{P}>0.05)$ for both systems (Table 2). However, during the transition from rainy to dry (P5) and from dry to rainy (P7) and also during the dry season (P6), the SPS produced more forage $(34 \%)$ than Mono $(\mathrm{P}<0.05)$. TDM production was affected $(\mathrm{P}<0.05)$ by harvest period $(\mathrm{P} 1-\mathrm{P} 7)$ for both SPS and Mono treatments, with highest yields during the initial period at the start of the rainy season and lowest during the dry season $(\mathrm{P}<0.05)$. Green leaf production in both systems followed that of TDM during the harvest periods.

Table 2. Total forage DM production and green leaf DM production for silvopastoral (SPS) and monoculture (Mono) systems during the harvest periods.

\begin{tabular}{|c|c|c|c|c|c|c|c|c|c|}
\hline \multirow[t]{3}{*}{ System } & \multicolumn{8}{|c|}{ Total forage DM production (t/ha) } & \multirow[b]{4}{*}{$\mathrm{P}^{*}$ System } \\
\hline & \multirow[b]{2}{*}{$\mathrm{P} 1 * *$} & \multicolumn{6}{|c|}{ Period } & \multirow[t]{2}{*}{ Total } & \\
\hline & & $\mathrm{P} 2 * *$ & $\mathrm{P} 3 * *$ & $\mathrm{P} 4$ & P5 & P6 & P7 & & \\
\hline SPS & $1.76 \mathrm{aD}$ & $1.29 \mathrm{aC}$ & $1.40 \mathrm{aC}$ & $1.27 \mathrm{aC}$ & $0.81 \mathrm{bB}$ & $0.48 \mathrm{bA}$ & $0.84 \mathrm{bB}$ & 7.84 & \\
\hline Mono & $1.85 \mathrm{aD}$ & $1.27 \mathrm{aC}$ & $1.45 \mathrm{aC}$ & $1.25 \mathrm{aC}$ & $0.41 \mathrm{aA}$ & $0.34 \mathrm{aA}$ & $0.68 \mathrm{aB}$ & 7.28 & 0.351824 \\
\hline Mean & 1.81 & 1.28 & 1.43 & 1.26 & 0.61 & 0.41 & 0.76 & 1.08 & $\mathrm{P}^{*}$ Period x System \\
\hline $\mathrm{P}^{*}$ Periods & & & & 0.0001425 & & & & & 0.000854 \\
\hline \multirow[t]{3}{*}{ System } & \multicolumn{8}{|c|}{ Green leaf DM production (t/ha) } & \\
\hline & & \multicolumn{6}{|c|}{ Period } & Total & \\
\hline & $\mathrm{P} 1 * *$ & $\mathrm{P} 2 * *$ & $\mathrm{P} 3 * *$ & P4 & P5 & P6 & P7 & & \\
\hline SPS & $1.35 \mathrm{aD}$ & $0.98 \mathrm{aC}$ & $1.05 \mathrm{aC}$ & $0.92 \mathrm{aC}$ & $0.43 \mathrm{bB}$ & $0.31 \mathrm{bA}$ & $0.48 \mathrm{bB}$ & 5.53 & $\mathrm{P}^{*}{ }_{\text {System }}$ \\
\hline Mono & $1.44 \mathrm{aE}$ & $0.99 \mathrm{aD}$ & $1.12 \mathrm{aD}$ & $0.94 \mathrm{aD}$ & $0.16 \mathrm{aB}$ & $0.09 \mathrm{aA}$ & $0.27 \mathrm{aC}$ & 5.00 & 0.27434 \\
\hline Mean & 1.47 & 1.03 & 1.14 & 0.98 & 0.29 & 0.21 & 0.38 & 0.79 & $\mathrm{P}^{*}$ Period x System \\
\hline $\mathrm{P}^{*}$ Periods & & & & 0.000123 & & & & & 0.001232 \\
\hline
\end{tabular}

P1-P4 = rainy season; P5 = transition period (rainy-dry); P6 = dry period; and P7 = transition period (dry-rainy).

* Type 1 error probability.

** Intake trial periods.

Means within a column with different lower-case letters differ significantly at $\mathrm{P}<0.05$ based on the Skott-Knott test.

Values within a row with different upper-case letters differ significantly at $\mathrm{P}<0.05$ based on the Skott-Knott test. 


\section{Microclimatic variables}

The daily average maximum temperature in Mono exceeded that in SPS (33.5 vs. $28.0{ }^{\circ} \mathrm{C}$; Table 3), while mean minimum temperatures did not differ (21.0 vs. $20.5^{\circ} \mathrm{C}$ ). In the SPS, mean dry bulb temperature (DBT) under the tree canopy was lower than in the monoculture at all daily recordings except $19.00 \mathrm{~h}$. The reverse was the case for relative humidity (Table 3 ), so that THI was greater in the monoculture only during the early part of the day, while BGTHI was greater in the monoculture for most of the day. Global radiation (Table 3) was higher in Mono than in SPS.

Regarding dry bulb temperature (DBT) (Table 4, Figure 3), data show that for monoculture, the day period with temperatures above the upper limit of the thermal comfort zone (TCZ) for sheep, which is $20-28{ }^{\circ} \mathrm{C}$ (Baêta and Souza 1997), was $4 \mathrm{~h} 55 \mathrm{~min}$. The temperatures in SPS also exceeded TCZ, but were lower than those recorded for the monoculture.

Table 3. Microclimatic variables in silvopastoral (SPS) and monoculture (Mono) systems.

\begin{tabular}{|c|c|c|c|c|c|c|c|c|}
\hline \multirow[t]{2}{*}{ System and parameter ${ }^{1}$} & \multirow[t]{2}{*}{ Day } & \multicolumn{6}{|c|}{ Time of day (h) } & \multirow[t]{2}{*}{ Mean } \\
\hline & & 07.00 & 09.00 & 11.00 & 13.00 & 17.00 & 19.00 & \\
\hline \multicolumn{9}{|l|}{ SPS } \\
\hline Max. temp. $\left({ }^{\circ} \mathrm{C}\right)$ & 28.0 & - & - & - & - & - & - & - \\
\hline Min. temp. $\left({ }^{\circ} \mathrm{C}\right)$ & 21.0 & - & - & - & - & - & - & - \\
\hline Dry bulb temp. $\left({ }^{\circ} \mathrm{C}\right)$ & & 19.0 & 22.8 & 24.8 & 27.6 & 26.2 & 24.0 & 24.1 \\
\hline Rel. humidity (\%) & & 100.0 & 84.5 & 75.5 & 60.6 & 56.1 & 80.6 & 76.2 \\
\hline THI & & 73.9 & 85.3 & 90.3 & 98.3 & 96.0 & 88.5 & 88.7 \\
\hline BGTHI & & 68.0 & 73.4 & 74.8 & 79.6 & 75.6 & 72.7 & 74.0 \\
\hline $\mathrm{GR}\left(\mathrm{W} / \mathrm{m}^{2} / \mathrm{d}\right)$ & & - & - & - & - & - & - & 398.7 \\
\hline \multicolumn{9}{|l|}{ Mono } \\
\hline Max. temp. $\left({ }^{\circ} \mathrm{C}\right)$ & 33.5 & - & - & - & - & - & - & - \\
\hline Min. temp. $\left({ }^{\circ} \mathrm{C}\right)$ & 20.5 & - & - & - & - & - & - & - \\
\hline Dry bulb temp. $\left({ }^{\circ} \mathrm{C}\right)$ & & 20.7 & 24.3 & 26.5 & 29.8 & 28.5 & 24.2 & 25.7 \\
\hline Rel. humidity (\%) & & 94.8 & 78.0 & 65.1 & 50.9 & 52.8 & 85.8 & 71.3 \\
\hline THI & & 79.3 & 89.1 & 93.3 & 99.3 & 96.1 & 86.6 & 90.6 \\
\hline BGTHI & & 71.8 & 78.8 & 81.6 & 89.1 & 81.3 & 72.6 & 79.2 \\
\hline $\mathrm{GR}\left(\mathrm{W} / \mathrm{m}^{2} / \mathrm{d}\right)$ & & - & - & - & - & - & - & 712.6 \\
\hline
\end{tabular}

${ }^{1} \mathrm{THI}=$ temperature and humidity index; BGTHI = black globe temperature and humidity index; GR = global radiation.

Table 4. Equations generated by regression analysis, relating microclimatic variable data in silvopastoral (SPS) and monoculture (Mono) systems.

\begin{tabular}{lclc}
\hline System & Microclimatic variable $^{1}$ & \multicolumn{1}{c}{ Equation $^{2}$} & $\mathrm{R}^{2}$ \\
\hline SPS & DBT & $\mathrm{y}=8.3+5.045 \mathrm{x}-0.174 \mathrm{x}^{2} \quad$ aA & 0.94 \\
Mono & DBT & $\mathrm{y}=-8.7+5.495 \mathrm{x}-0.198 \mathrm{x}^{2} \quad$ bB & 0.92 \\
SPS & RH & $\mathrm{y}=219.7-21.95 \mathrm{x}+0.755 \mathrm{x}^{2}$ bB & 0.88 \\
Mono & RH & $\mathrm{y}=246.4-28.26 \mathrm{x}+1.025^{2} \quad$ aA & 0.89 \\
SPS & THI & $\mathrm{y}=6.7+12.57 \mathrm{x}-0.433 \mathrm{x}^{2} \quad$ aA & 0.98 \\
Mono & THI & $\mathrm{y}=17.5+11.72 \mathrm{x}-0.422 \mathrm{x}^{2} \quad$ bB & 0.97 \\
SPS & BGTHI & $\mathrm{y}=34.4+6.316 \mathrm{x}-0.230 \mathrm{x}^{2} \quad$ aA & 0.91 \\
Mono & BGTHI & $\mathrm{y}=5.6+12.59 \mathrm{x}-0.477 \mathrm{x}^{2}$ bB & 0.92 \\
\hline
\end{tabular}

${ }^{1} \mathrm{DBT}=$ dry bulb temperature $\left({ }^{\circ} \mathrm{C}\right) ; \mathrm{RH}=$ relative humidity $(\%)$; THI $=$ temperature and humidity index; BGTHI $=$ black globe temperature and humidity index; $y=$ microclimatic variable; $x=$ time of measurement $(07.00,09.00,11.00,13.00,17.00$ and $19.00 \mathrm{~h})$. ${ }^{2}$ Equations relating to the same microclimatic variable followed by different upper-case letters are not parallel by the curve parallelism test (Cohen 1983) at 5\% probability; equations relating to the same microclimatic variable followed by different lower-case letters differ by the curve identity test (Cohen 1983) at 5\% probability. 


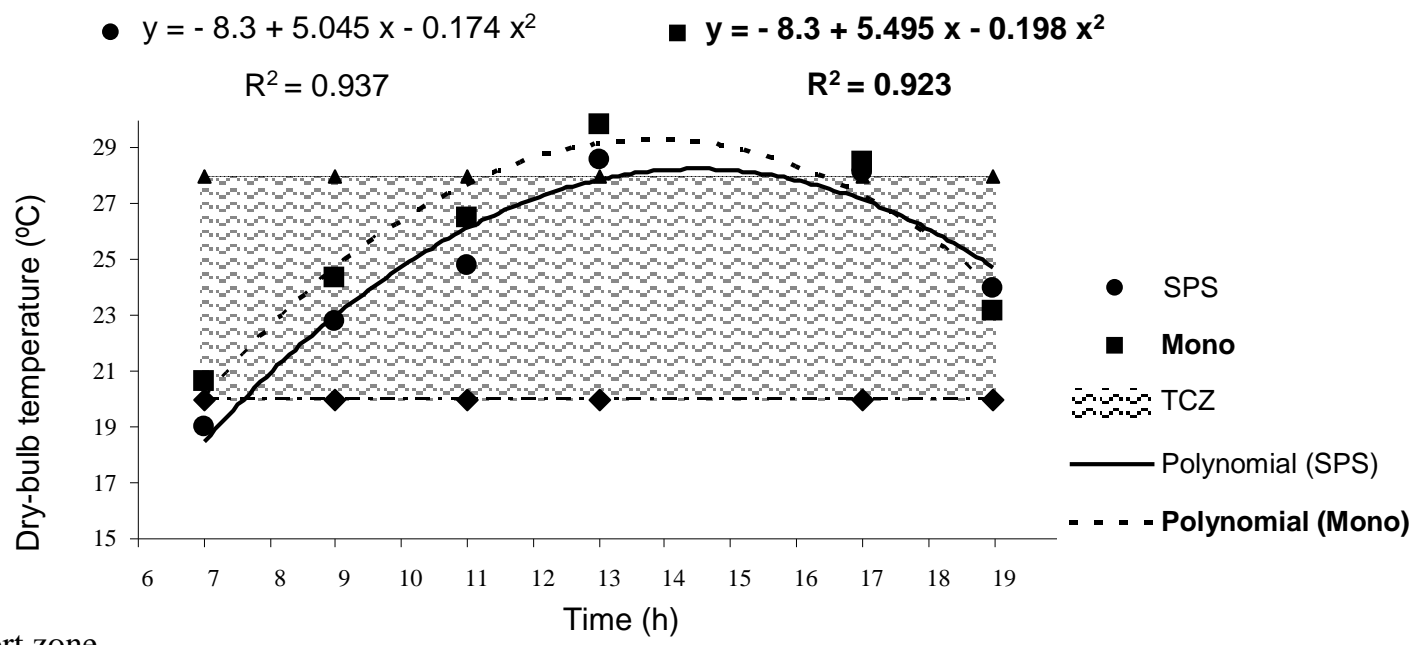

$\mathrm{TCZ}=$ thermal comfort zone .

Figure 3. Dry bulb temperature (DBT) in silvopastoral (SPS) and monoculture (Mono; in bold) systems during the day.

Relative humidity throughout the day, with the exception of 07.00 and $09.00 \mathrm{~h}$ for the SPS and $7.00 \mathrm{~h}$ for Mono (Table 4; Figure 4), was within the range of thermal comfort for the animals, which should be between 50 and $80 \%$ (Baêta and Souza 1997). Table 4 shows that there were significant differences $(\mathrm{P}<0.05)$ for $\mathrm{RH}$ between treatments and those were more pronounced in the period between 10.00 and $16.00 \mathrm{~h}$ (Figure 4).

Results indicate that in both systems, THI was almost always within the "scale of extremely severe heat stress" (LPHSI 1990). This occurs because the trial was done in December, when this index reaches its highest values of the year. However, even under these conditions, SPS showed lower values $(\mathrm{P}<0.05)$ than those for the monoculture (Table 4; Figure 5).

For BGTHI, significant differences were observed $(\mathrm{P}<0.05)$ between the systems (Table 4), with a lower value in SPS than in Mono, which indicates milder microclimatic conditions in shaded pastures (Figure 6).

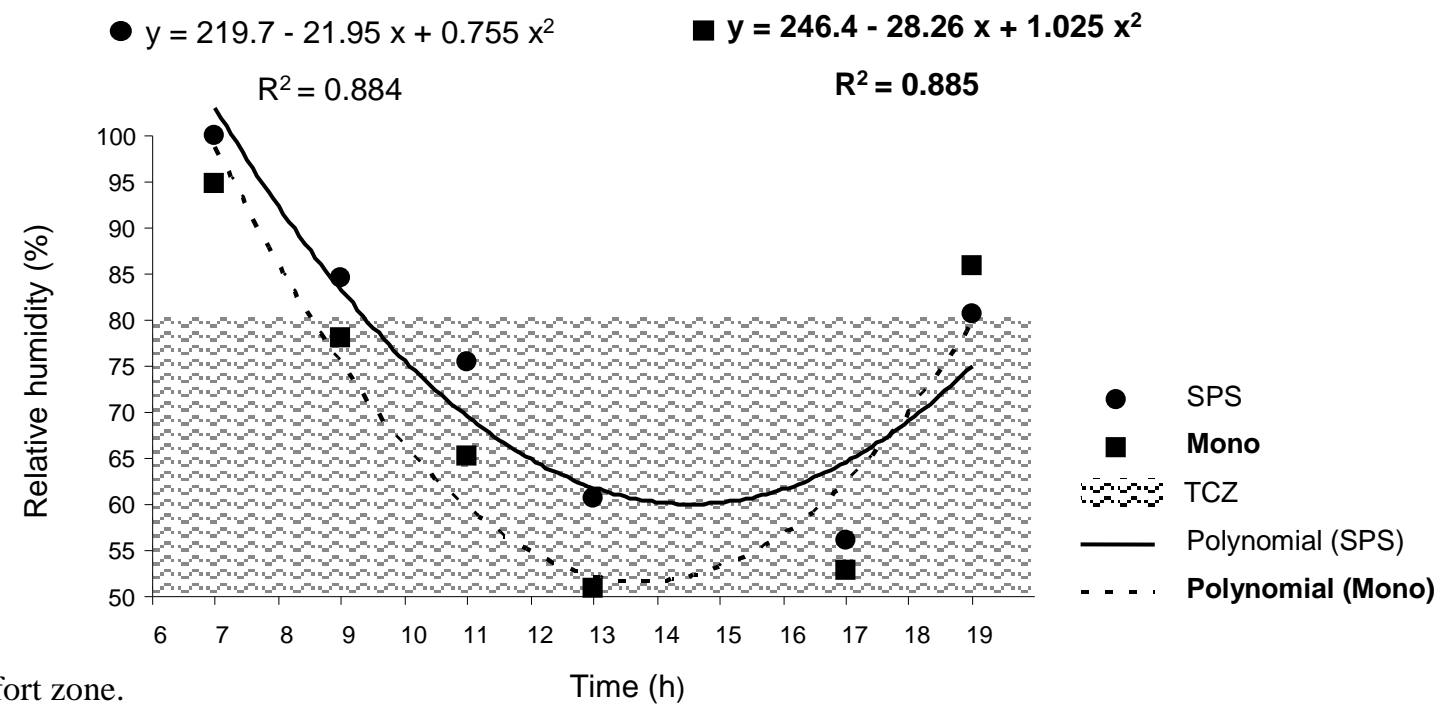

$\mathrm{TCZ}=$ thermal comfort zone

Figure 4. Relative humidity (RH) in silvopastoral (SPS) and monoculture (Mono; in bold) systems during the day. 


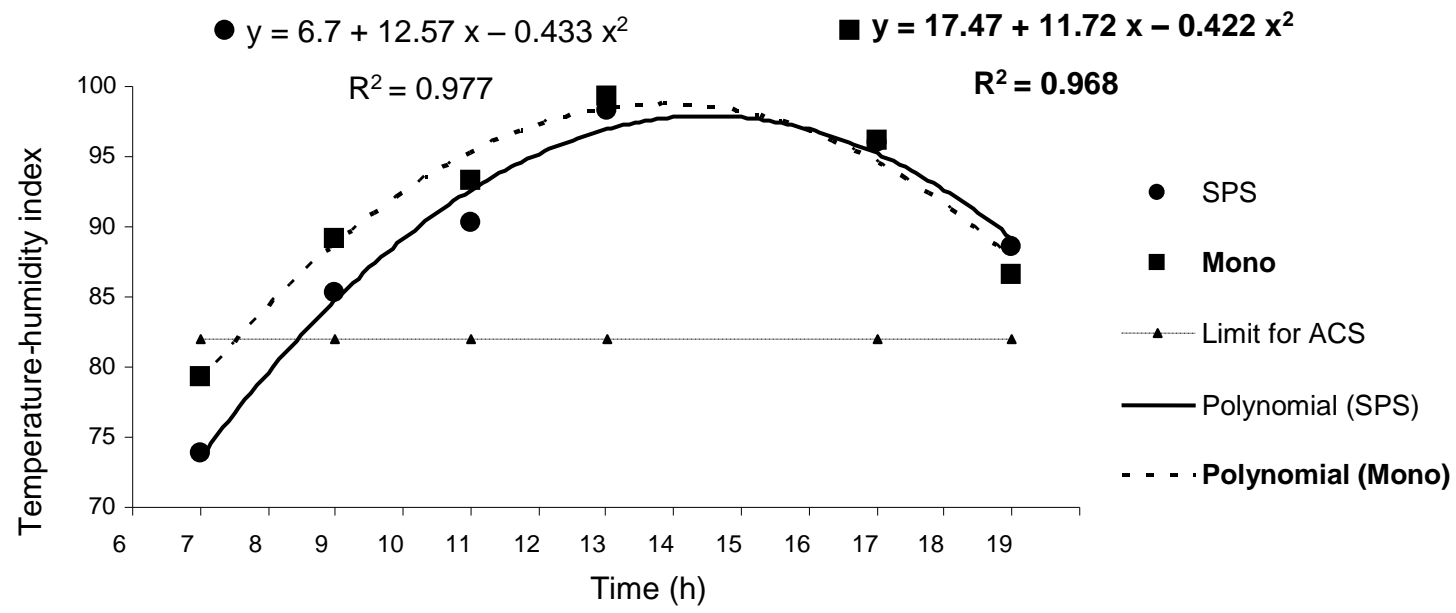

Limit for ACS = Limit below which there is absence of caloric stress.

Figure 5. Temperature humidity index (THI) for silvopastoral (SPS) and monoculture (Mono; in bold) systems during the day.

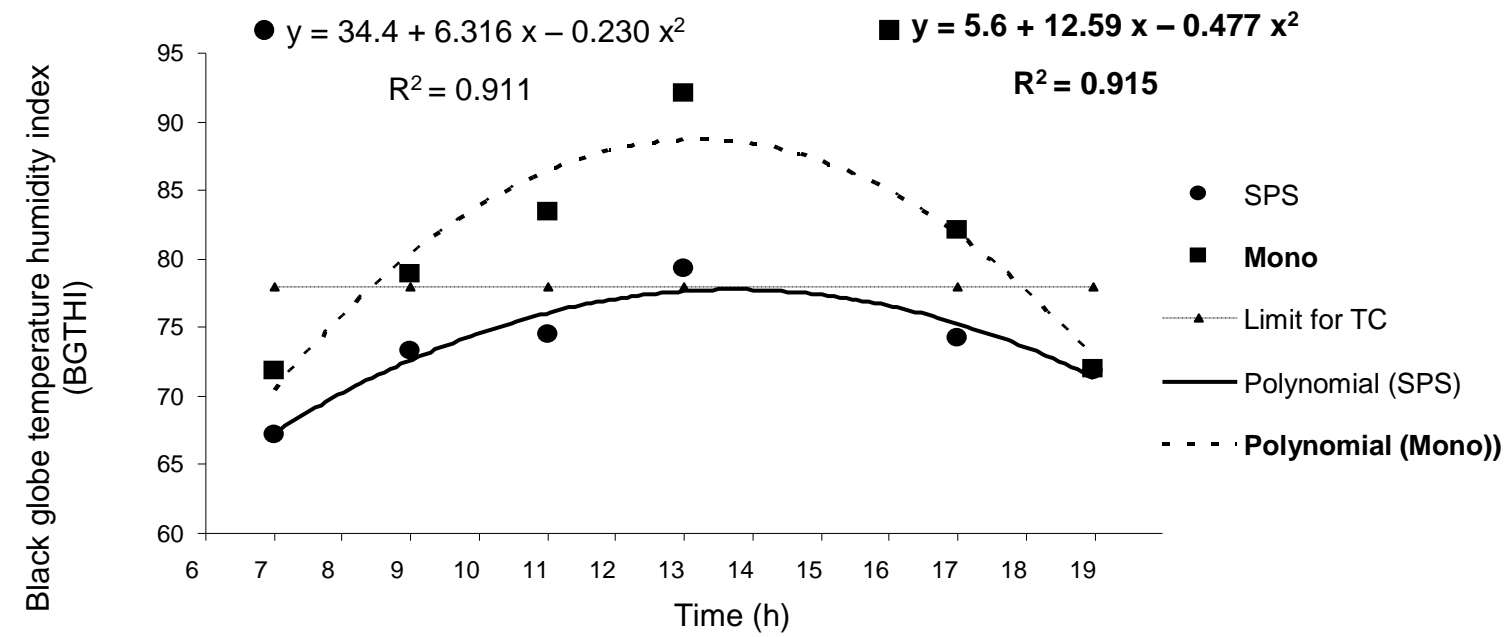

Limit for $\mathrm{TC}=$ Limit below which there is thermal comfort.

Figure 6. Black globe temperature humidity index (BGTHI) for the silvopastoral (SPS) and monoculture (Mono; in bold) systems during the day.

\section{Intake}

Nutritive value of Marandu grass samples was similar in both systems, except for DM content and for nitrogen fractions linked to the fibrous portion of the forage (Table 5). Both DMI and OMI by sheep in the SPS system were higher $(\mathrm{P}<0.05)$ than those in the monoculture (Table 6). Free water intake was lower and intake of water in the feed was higher $(\mathrm{P}<0.05)$ in the SPS (Table 6) than in Mono. Total water intake was $10.2 \%$ higher $(\mathrm{P}<0.05)$ in the Mono than in the SPS. 
Table 5. Chemical composition of samples from simulated grazing in silvopastoral (SPS) and monoculture (Mono) systems.

\begin{tabular}{lrr}
\hline Parameter $^{1}$ & \multicolumn{2}{c}{ System } \\
\cline { 2 - 3 } & \multicolumn{2}{c}{ SPS } \\
\hline DM (g DM/kg fresh) & 202.3 & Mono \\
Organic matter (g/kg DM) & 911.9 & 252.7 \\
Ash (g/kg DM) & 88.1 & 83.8 \\
Crude protein (g/kg DM) & 121.8 & 118.1 \\
NDF (g/kg DM) & 664.7 & 648.7 \\
ADF (g/kg DM) & 318.3 & 310.6 \\
Lignin (g/kg DM) & 25.6 & 23.0 \\
Silica (g/kg DM) & 2.5 & 4.8 \\
INND (g/kg TN) & 180.5 & 98.7 \\
INAD (g/kg TN) & 19.8 & 34.7 \\
IVDMD (g DM/kg DM) & 59.3 & 60.8 \\
IVOMD (g OM/kg OM) & 58.5 & 59.0 \\
\hline
\end{tabular}

${ }^{1} \mathrm{DM}=$ dry matter; INND = insoluble nitrogen in neutral detergent; INAD = insoluble nitrogen in acid detergent; TN = total nitrogen; IVDMD = in vitro dry matter digestibility; IVOMD = in vitro organic matter digestibility.

Table 6. Intake of dry matter, organic matter and water of sheep grazing in silvopastoral (SPS) and monoculture (Mono) systems.

\begin{tabular}{|c|c|c|c|c|}
\hline Parameter & SPS & Mono & m.s.e. & $\mathrm{P}$ \\
\hline \multicolumn{5}{|l|}{ DM intake } \\
\hline (g DM/kg LW/d) & 38.9 & 35.2 & 0.62 & $<0.001$ \\
\hline$\left(\mathrm{g} \mathrm{DM} / \mathrm{kg}^{0.75} \mathrm{LW} / \mathrm{d}\right)$ & 88.2 & 79.9 & 1.14 & $<0.001$ \\
\hline \multicolumn{5}{|l|}{ OM intake } \\
\hline (g OM/kg LW/d) & 37.3 & 34.6 & 0.68 & $<0.001$ \\
\hline$\left(\mathrm{g} \mathrm{OM} / \mathrm{kg}^{0.75} \mathrm{LW} / \mathrm{d}\right)$ & 86.4 & 78.6 & 1.15 & $<0.001$ \\
\hline \multicolumn{5}{|c|}{ Water intake $\left(\mathrm{mL} / \mathrm{kg}^{0.75} \mathrm{LW} / \mathrm{d}\right)$} \\
\hline Free water intake ${ }^{1}$ & 82 & 238 & & \\
\hline Feed water intake ${ }^{2}$ & 348 & 236 & 4 & $<0.001$ \\
\hline Total water intake & 430 & 474 & 6 & $<0.021$ \\
\hline
\end{tabular}

m.s.e. $=$ mean standard error.

${ }^{1}$ water used from drinking spouts.

${ }^{2}$ moisture in forage consumed.

\section{Feeding behavior}

Time periods spent grazing were longer $(\mathrm{P}<0.001)$ in the SPS than in Mono. On the other hand, animals spent more time walking $(\mathrm{P}<0.001)$, drinking $(\mathrm{P}=0.016)$ and resting $(\mathrm{P}=0.008)$ in Mono, than in SPS (Table 7). Time spent ruminating and in other activities did not differ $(\mathrm{P}>0.05)$ between systems.

Table 7. Feeding behavior parameters (min/d) for silvopastoral (SPS) and monoculture (Mono) systems.

\begin{tabular}{lcccr}
\hline Activity & SPS & Mono & m.s.e. & P \\
\hline Grazing & 572 & 288 & 43 & $<0.001$ \\
Ruminating & 300 & 280 & 43 & 0.179 \\
Resting & 188 & 373 & 22 & 0.008 \\
Walking & 30 & 89 & 10 & $<0.001$ \\
Drinking & 20 & 53 & 7 & 0.016 \\
Other & 330 & 357 & 8 & 0.217 \\
\hline
\end{tabular}




\section{Discussion}

This study provides sound evidence that SPS provide advantages over a grass monoculture in this region in terms of pasture growth during dry periods and comfort of animals, resulting in improved feed intake and, probably, production. The study had some limitations, the main one being that we used animals as replicates inside single plots (i.e. areas). Ideally treatments should have been replicated in the experimental design with repetition over time. However, due to prohibitive costs, lack of funding, deficiency in labor and project size, the design of this experiment was not ideal. Nevertheless, inferences are valid and information provided met the objectives of this study.

\section{Forage production}

It was interesting that SPS produced $8 \%$ more forage grass during the year than the control despite the competition from trees and lower global radiation values. This advantage occurred during the transition periods and dry season (50\% increase) with no difference during the wet season. In a tree-pasture system there is competition between the trees and the pasture for moisture and nutrients. In addition, shading can have negative impacts on DM production of pasture (Jackson and Ash 1998), which can be reflected in reduced animal production rates (Parsons et al. 1983). However, forage production is also dependent on other environmental parameters such as rainfall and temperature as well as soil moisture and soil fertility (Paciullo et al. 2011), which may counteract the negative effects of shade on DM production. It would seem that pastures in the silvopastoral system received a benefit from shading during the drier part of the year, possibly because of retention of soil moisture under the trees or better availability of nutrients as a result of recycling by the trees or a combination of these factors. In SPS, only $68 \%$ of the total pasture production occurred during the rainy season (P1-P4), while the control produced $75 \%$ of its growth during this period.

\section{Microclimatic variables}

The daily average maximum temperature (MaxTemp) in Mono $\left(33.5^{\circ} \mathrm{C}\right)$ was outside the thermal comfort zone (TCZ) for adult sheep in the tropics, which should be between 20 and $28{ }^{\circ} \mathrm{C}$ (Baêta and Souza 1997), while MaxTemp in SPS, which was $5.5^{\circ} \mathrm{C}$ lower than in the control, remained within the TCZ (Table 3). Daily average minimum temperatures (MinTemp) remained within the TCZ for both systems. This suggests that sheep graz- ing on Marandu in monoculture would have suffered heat stress during the hottest hours of the day, as reported by Baumgard and Rhoads (2012). Shading imposed by the tree component would have attenuated the incident radiation and reduced air temperature, reducing the severity of microclimatic stresses experienced in the straight grassland ecosystem. According to Sousa et al. (2010), air dry bulb temperature (DBT) under the canopy of trees can be $2.3-9.5{ }^{\circ} \mathrm{C}$ lower than in grass monoculture, depending on time of day.

On the other hand, RH values in SPS were always higher than those observed in monoculture and were above those reported by Sousa et al. (2010). It is well documented that biotic components such as trees and canopy architecture affect relative humidity (Daly 1984; Qin et al. 2014). However, despite these differences, the values for RH were within the range of thermal comfort for sheep according to LPHSI (1990). High RH affects heat dissipation with long exposure and causes ethological changes in ruminants (Ungar 1996). However, when analyzed separately it is not considered a suitable parameter for assessing thermal comfort in sheep (Baêta and Souza 1997). Sheep can become acclimatized to high levels of humidity, which provides significant changes in thermal sensations, i.e. the perceptions of the physiological effects caused by temperature variations, making sheep suffer less from the effects of heat stress under these conditions (Andrade et al. 2007). Thus, higher humidity conditions in the SPS (Table 3) may have been offset by the adaptation of experimental animals.

According to LPHSI (1990), THI values for sheep above 86 should produce severe heat stress; that is, in both systems evaluated, only at $07.00 \mathrm{~h}$ would the animals not have suffered from some effects of tropical heat. Neiva et al. (2004), working in the northeast region of Brazil $\left(05^{\circ} 43^{\prime} 02^{\prime \prime} \mathrm{S}, 38^{\circ} 32^{\prime} 35^{\prime \prime} \mathrm{W}\right)$, observed that, even under complete shading (stabled animals), the value of THI (81.1) was similar to that obtained at full sunshine (82.3) and thermal stress was observed in sheep under both sets of conditions. These values may be associated with tropical climatic conditions, which have no defined parameters, and therefore do not correlate with the parameters generated by the Livestock and Poultry Heat Stress Indices (LPHSI 1990). These findings suggest that, while SPS evaluated in this study increased the comfort of sheep over the control treatment, it might still have failed to eliminate environmental heat stress in grazing sheep (average THI 89.7). BGTHI values (Table 3 ) evaluated in the SPS were always lower than those measured in monoculture and were always below the critical value $($ BGTHI $=78)$, above which heat 
stress could cause various metabolic problems in cattle (Andrade et al. 2007). However, no critical value for sheep was found in the literature.

\section{Intake}

Differences in chemical composition, IVDMD and IVOMD of the forage grass in both systems (Table 5) were small and would not justify the superiority of 9.47\% in DMI (g DM/ $/ \mathrm{kg}^{0.75} \mathrm{LW} / \mathrm{d}$ ) and $9.43 \%$ in OMI (g OM/kg ${ }^{0.75} \mathrm{LW} / \mathrm{d}$ ) in the SPS relative to Mono (Table $6)$. Thus, the differences in intake probably occurred because of better microclimatic conditions in the SPS (Tables 3 and 4), since the better thermal comfort provided lesser restriction on metabolic and dietary thermogenesis (Forbes 1995). According to Baumer (1991), animals protected from the heat increase DMI and produce more meat and milk. Minson (1990) reported an average value for voluntary intake by sheep fed tropical grass (separated leaf and stem of 6 and 12 week regrowth) of the genera Digitaria and Chloris of $46 \mathrm{~g} \mathrm{DM} /$ $\mathrm{kg}^{0.75} \mathrm{LW} / \mathrm{d}$. This value is much lower than that found in this study ( $\left.80 \mathrm{~g} \mathrm{DM} / \mathrm{kg}^{0.75} \mathrm{LW} / \mathrm{d}\right)$. The nutrient requirements of small ruminants (National Research Council 2007) specify intake values from 70 to $85 \mathrm{~g} \mathrm{DM} / \mathrm{kg}^{0.75}$ LW/d for Brachiaria decumbens and B. brizantha. While intake values (\% LW) of DM and OM in SPS were higher than in Mono, intakes in both systems were similar to those estimated by National Research Council (2007) for adult sheep with average weight of $30 \mathrm{~kg}$ and weight gain of $0.2 \mathrm{~kg} / \mathrm{d}$, i.e. $36.7 \mathrm{~g} \mathrm{DM} / \mathrm{kg} \mathrm{LW} / \mathrm{d}$. Shading obviously benefited forage intake by animals in the SPS relative to those in full sunlight on monoculture (Table 6). Samarakoon et al. (1990) evaluated the effect of growing 2 subtropical grasses, Stenotaphrum secundatum and Pennisetum clandestinum, under artificial shade (50\%) on DMI by sheep and found that shading reduced DMI. This was probably due to increasing levels of ADF in shaded grass with resultant decline in IVDMD and not due to any physiological effect of shade on sheep. In our study, pasture from SPS contained higher levels of fiber than in the control, and lower digestibility, but differences were small.

Total water intake by sheep on the control treatment was $11 \%$ higher than on the silvopastoral system, reflecting the greater heat stress suffered by those sheep. According to Baumer (1991), animals protected from the heat may reduce water intake by up to $20 \%$. Interestingly, the higher moisture content in forage on SPS coupled with the higher feed intake on this treatment resulted in most of the water requirements of the shaded sheep being satisfied from the feed consumed (81\%). This behavior is in accordance with the findings of Andrade et al. (2007), who suggest that grazing sheep under environmental conditions within the thermal comfort zone obtain $75-85 \%$ of their water needs from green forage. Not only was moisture requirement of sheep on the monoculture higher than in SPS but a greater percentage was derived from free water supplies. This is an obvious advantage for the silvopastoral system of having to provide less free water to stock.

\section{Feeding behavior}

The greater amount of time spent by animals in the monoculture in walking, drinking and resting is indicative of behaviors that seek to mitigate thermal stress, by maintaining thermal homeostasis and reducing metabolic stress (Ashutosh et al. 2002). Forbes (1995) claims that sheep have the ethological habit of trading grazing time for walking in search of shade during the hottest hours of the day. However, this occurs not only for physiological reasons, such as heat stress, but also the ancestral instinct of protection and escape from predators (Ryder 1984).

\section{Conclusions}

This study has shown the benefits of a silvopastoral system for sheep production through reduction in heat stress, resulting in higher feed intake. It appears that silvopastoral systems could be more productive than straight grass systems for mongrel hair sheep under these environmental conditions and the increases in growth rates etc. should be documented. However, the extent to which these results can be extrapolated to cattle needs to be verified before benefits for bovines can be claimed.

\section{Acknowledgments}

The authors thank Prof. Lúcio Carlos Gonçalves for his constructive suggestions on the elaboration of this study, and the Departamento de Engenharia de Biossistemas (DEPEB-PPBE), FAPEMIG, CNPq, PVE-CAPES and CAPES-EMBRAPA, RumenGases.

\section{References}

Andrade IS; Souza BB; Pereira Filho JM; Silva AM. 2007. Parâmetros fisiológicos e desempenho de ovinos Santa Inês submetidos a diferentes tipos de sombreamento e a suplementação em pastejo. Ciência e Agrotecnologia 31:540-547. DOI: 10.1590/s1413-70542007000200039 
AOAC (Association of Official Analytical Chemists). 2009. Official Methods of Analysis. 15th Edn. AOAC, Arlington, VA, USA.

Asthutosh F; Dhanoa OP; Singh G. 2002. Changes in grazing behaviour of native and crossbred sheep in different seasons under semi-arid conditions. Tropical Animal Health and Production 34:399-404. DOI: 10.1023/A:10200442 $\underline{26250}$

Baêta FC; Souza C. 1997. Ambience in rural buildings: Thermal comfort. UFV Press, Universidade Federal de Viçosa, Viçosa, MG, Brazil.

Baumer M. 1991. Animal production, agroforestry and similar techniques. Agroforestry Abstracts 4:179-198.

Baumgard LH; Rhoads RP. 2012. Ruminant Nutrition Symposium: Ruminant production and metabolic responses to heat stress. Journal of Animal Science 90:1855-1865. DOI: $10.2527 /$ jas.2011-4675

Bocquier F; González-García E. 2010. Sustainability of ruminant agriculture in the new context: Feeding strategies and features of animal adaptability into the necessary holistic approach. Animal 4:1258-1273. DOI: $10.1017 / \mathrm{S} 175173$ 1111001261

Boeriu CG; Bravo D; Gosselink RJA; Van Dam JEG. 2004. Characterisation of structure-dependent functional properties of lignin with infrared spectroscopy. Industrial Crops and Products 20:205-218. DOI: 10.1016/j.indcrop. 2004.04.022

Buffington DE; Colazzo-Arocho A; Canton GH; Pitt D; Thatcher WW; Collier RJ. 1981. Black globe-humidity index (BGHI) as comfort equation for dairy cows. Transactions of the ASAE 24:711-714. DOI: 10.13031/2013. $\underline{34325}$

Cohen A. 1983. Comparing regression coefficients across subsamples: A study of the statistical test. Sociological Methods and Research 12:77-94. DOI: 10.1177/0049 124183012001003

Costa NL; Gonçalves CA; Oliveira JRC; Oliveira MAS; Magalhães JA. 2004. Resposta de Brachiaria brizantha cv. Marandu à regimes de corte. Comunicado técnico 279, Embrapa Rondônia, Porto Velho, RO, Brazil. http://goo.gl/hJGeYn

Daly JJ. 1984. Cattle need shade trees. Queensland Agricultural Journal 110:21-24.

Dumont B; Fortun-Lamothe L; Jouven M; Thomas M; Tichit M. 2013. Prospects from agroecology and industrial ecology for animal production in the 21 st century. Animal 7:1028-1043. DOI: $\underline{10.1017 / S 175173111200}$ $\underline{2418}$

Ferreira MA; Valadares Filho SC; Marcondes MI; Paixão ML; Paulino MF; Valadares RFD. 2009. Evaluation of markers in ruminant trials: Digestibility. Brazilian Journal of Animal Science 38:1568-1573. http://goo.gl/Fj0G6X

Forbes JM. 1995. Voluntary food intake and diet selection in farm animals. CABI Publishing, Wallingford, UK.

Jackson J; Ash AJ. 1998. Tree-grass relationships in open eucalypt woodlands of northeastern Australia: Influence of trees on pasture productivity, forage quality and species distribution. Agroforestry Systems 40:159-176. DOI: 10.1023/A:1006067110870

Johnson AD. 1978. Sample preparation and chemical analysis of vegetation. In: Mannetje L't, ed. Measurement of grassland vegetation and animal production. Commonwealth Agricultural Bureaux, Aberystwyth, UK. p. 96-102.

Kelly CF; Bond TE. 1971. Bioclimatic factors and their measurements. In: Kelly FC; Bond TE, eds. A guide to environmental research on animals. National Academy of Sciences, Washington, DC, USA. p. 7-92.

Licitra G; Hernandez TM; Van Soest PJ. 1996. Standardization of procedures for nitrogen fractionation of ruminant feeds. Animal Feed Science and Technology 57:347-358. DOI: $\underline{\text { 10.1016/0377-8401(95)00837-3 }}$

LPHSI. 1990. Livestock and Poultry Heat Stress Indices. Agriculture Engineering Technology Guide, Clemson University, Clemson, SC, USA.

Maurício RM. 2012. Comment to "Pasture shade and farm management effects on cow productivity in the tropics" by Ainsworth Justin AW; Moe Stein R; Skarpe C (Agriculture, Ecosystems and Environment 155:105-110). Agriculture, Ecosystems and Environment 161:78-79. DOI: 10.1016/j.agee.2012.07.012

Minson DJ. 1990. Forage in ruminant nutrition. Academic Press, New York, USA.

National Research Council. 2007. Nutrient Requirements of Small Ruminants: Sheep, Goats, Cervids, and New World Camelids. National Academies Press, Washington, DC, USA.

Neiva JNM; Teixeira M; Turco SHN; Oliveira SMP; Moura AAAN. 2004. Effects of environmental stress on physiological parameters of feedlot sheep in the northeast of Brazil. Brazilian Journal of Animal Science 33:668-678. http://goo.gl/eHbJjr

Paciullo DSC; Castro CRR; Gomide CAM; Maurício RM; Pires MFA; Müller MD; Xavier DF. 2011. Performance of dairy heifers in a silvopastoral system. Livestock Science 141:166-172. DOI: $10.1017 /$ S1751731114000767

Parsons AJ; Leafe EL; Collett B; Penning PD; Lewis J. 1983. The physiology of grass production under grazing. II. Photosynthesis, crop growth and animal intake of continuously-grazed swards. Journal of Applied Ecology 20:127-139. DOI: $10.2307 / 2403381$

Prigge EC; Varga GA; Vicini JL; Reid RL. 1981. Comparison of ytterbium chloride and chromium sesquioxide as fecal indicators. Journal of Animal Science 53:1629-1633. DOI: 10.2134/jas 1982.5361629x

Qin Z; Li Z; Cheng F; Chen J; Liang B. 2014. Influence of canopy structural characteristics on cooling and humidifying effects of Populus tomentosa community on calm sunny summer days. Landscape and Urban Planning 127:7582. DOI: 10.1016/j.landurbplan.2014.04.006

Reis GL; Lana AMQ; Maurício RM; Lana RMQ; Machado RM; Borges I; Quinzeiro Neto T. 2009. Influence of trees on soil nutrient pools in a silvopastoral system in the Bra- 
zilian Savannah. Plant and Soil 323:11-16. DOI: $\underline{10.1007 /}$ s11104-009-0144-5

Ryder ML. 1984. Evolution of domesticated animals. In: Mason IL, ed. Sheep. Longman, New York, USA. p. 63-85.

Samarakoon SP; Shelton HM; Wilson JR. 1990. Voluntary feed intake by sheep and digestibility of shaded Stenotaphrum secundatum, Axonopus compressus and Pennisetum clandestinum herbage. Journal of Agricultural Science 114:143-150. DOI: 10.1017/S0021859600072129

Sousa LF; Maurício RM; Moreira GR; Gonçalves LC; Borges I; Pereira LGR. 2010. Nutritional evaluation of "Braquiarão" grass in association with "Aroeira" trees in a silvopastoral system. Agroforestry Systems 79:189-199. DOI: $10.1007 / \mathrm{s} 10457-010-9297-8$

Theander O; Westerlund EA. 1986. Studies on dietary fibre. 3. Improved procedures for analysis on dietary fibre. Journal of Agriculture and Food Chemistry 34:330-336. DOI: $10.1021 / \mathrm{jf00068 \textrm {a } 0 4 5}$

Ungar ED. 1996. Ingestive behaviour. In: Hodgson J; Illius A, eds. The ecology and management of grazing systems. Oxford University Press, Oxford, UK. p. 185-218.

Van Soest PJ; Robertson JB; Lewis BA. 1991. Methods for dietary fiber, neutral detergent fiber and nonstarch polysaccharides in relation to animal nutrition. Journal of Dairy Science 74:3583-3597. DOI: 10.3168/jds.S0022-0302(91) 78551-2

Wilson JR; Hill K; Cameron DM; Shelton HM. 1990. The growth of Paspalum notatum under the shade of a Eucalyptus grandis plantation canopy or in full sun. Tropical Grasslands 24:24-28. http://goo.gl/MlFwI9

(Received for publication 27 March 2014; accepted 19 May 2015)

(C) 2015

\section{(c) (1) (5) (2)}

Tropical Grasslands-Forrajes Tropicales is an open-access journal published by Centro Internacional de Agricultura Tropical (CIAT). This work is licensed under a Creative Commons Attribution-NonCommercial-ShareAlike 3.0 Unported License. To view a copy of this license, visit http://creativecommons.org/licenses/by-nc-sa/3.0/ 